\title{
Precapillary Pulmonary Hypertension and Sleep-Disordered Breathing: Is There a Link?
}

\author{
Robert Thurnheer $^{\mathrm{a}}$ Silvia Ulrich ${ }^{\mathrm{b}}$ Konrad E. Bloch ${ }^{\mathrm{b}, \mathrm{c}}$ \\ ${ }^{a}$ Department of Internal Medicine, Pulmonary Division and Sleep Disorders Center, Cantonal Hospital \\ Münsterlingen, Münsterlingen, and b ${ }^{b}$ Pulmonary Division, Sleep Disorders Centre and Pulmonary Hypertension \\ Clinic, University Hospital Zurich, and ' ${ }^{C}$ Centre for Interdisciplinary Sleep Research, University of Zurich, \\ Zurich, Switzerland
}

\section{Keywords}

Pulmonary hypertension - Sleep-related breathing disorders · Sleep apnea - Cheyne-Stokes respiration .

Heart failure

\begin{abstract}
Among patients with sleep apnea the reported prevalence of precapillary pulmonary hypertension $(\mathrm{PH})$ has varied largely, depending on patient selection, disease definition, and associated conditions, in particular chronic pulmonary disease. However, in the absence of comorbidities, $\mathrm{PH}$ seems to be rare in patients with sleep apnea. Conversely, sleeprelated breathing disorders have been commonly found in patients with $\mathrm{PH}$ and they have been associated with an impaired quality of life. Since sleep-related breathing disorders may affect the pulmonary circulation and vice versa, patients with sleep-related breathing disorders should be evaluated for risk factors, symptoms and clinical signs of $\mathrm{PH}$ and right ventricular heart failure and patients with $\mathrm{PH}$ should be evaluated for sleep apnea. Therapeutic options for patients with sleep apnea and PH may include supplemental oxygen, drugs and positive pressure ventilation. Both nocturnal oxygen administration and acetazolamide have been shown to
\end{abstract}

๑ 2016 S. Karger AG, Basel improve sleep apnea in patients with $\mathrm{PH}$. In addition, oxygen therapy also improved exercise performance. Further studies are needed to corroborate the efficacy of these and other treatments.

(c) 2016 S. Karger AG, Basel

\section{Introduction}

Precapillary pulmonary hypertension $(\mathrm{PH})$ and right ventricular heart failure occur in certain patients with sustained hypoxemia due to obesity hypoventilation syndrome [1] and severe sleep-related hypoventilation, and in high-altitude residents suffering from chronic mountain sickness [2]. Whether precapillary PH may also develop as a consequence of intermittent hypoxemia during sleep such as in patients with obstructive sleep apnea (OSA) is controversial. While up to $50 \%$ of adults in Western countries are estimated to be affected by various severities of OSA [3-5], only a minor fraction of these individuals are considered to suffer from precapillary $\mathrm{PH}$ [6]. Conversely, among patients with precapillary $\mathrm{PH}$, either pulmonary arterial or chronic thromboembolic (WHO classes I or IV), a high prevalence of central sleep

\section{KARGER}

E-Mail karger@karger.com

www.karger.com/res
Konrad E. Bloch, MD

Pulmonary Division and Sleep Disorders Centre University Hospital Zurich

Rämistrasse 100, CH-8091 Zurich (Switzerland)

E-Mail konrad.bloch@usz.ch 
apnea (CSA) and OSA has been observed suggesting a pathophysiologic link [7].

In patients with postcapillary $\mathrm{PH}$ due to severe left ventricular heart failure (WHO class II), Cheyne-Stokes respiration/CSA (CSR/CSA) is quite common and this association is considered to indicate a poor prognosis. Compared to sleep-disordered breathing (SDB) in the context of left ventricular failure, which has been the topic of a review article in this journal [8], SDB in association with precapillary $\mathrm{PH}$ has gained much less attention. Therefore, the aim of the current review is to analyze the literature on this association with a particular focus on the pathophysiologic mechanisms linking SDB and precapillary $\mathrm{PH}$. We further review the prevalence and importance of precapillary $\mathrm{PH}$ in patients with SDB and of SDB in patients with $\mathrm{PH}$, and we analyze the prognostic and therapeutic implications of SDB in association with $\mathrm{PH}$.

\section{Mechanisms Linking Precapillary PH and SDB}

During normal sleep, there is a fall in heart rate and systemic arterial blood pressure with lowest values in deep non-rapid eye movement (NREM) sleep [9]. In rapid eye movement (REM) sleep, pulmonary arterial pressure (PAP) becomes unstable and increases compared to NREM sleep [10]. However, no relevant differences in PAP were seen between the first and the second half of a night in healthy individuals, which may indicate a lack of dependence of PAP on NREM and REM sleep stage [11].

Excessive rises in PAP and SDB may be mutually linked by either direct effects or via comorbid conditions (Fig. 1). Thus, hypoxemia during sleep due to hypoventilation or apneas/hypopneas may induce $\mathrm{PH}$ through hypoxic and/ or hypercapnic pulmonary vasoconstriction and sympathetic activation as detailed below. Conversely, it has been suggested that precapillary $\mathrm{PH}$ associated with right ventricular failure may promote instability of ventilatory control leading to sleep apnea through similar mechanisms as in left ventricular failure with CSR/CSA [12]. Furthermore, patients suffering from SDB in association with other conditions predisposing to an elevated PAP such as chronic lung disease, in particular chronic obstructive pulmonary disease (COPD), chronic alveolar hypoventilation related to chest wall deformities or neuromuscular disease with respiratory muscle weakness, may be susceptible to developing precapillary $\mathrm{PH}$. According to epidemiologic studies in overweight patients, both hypoxia and hypercapnia are associated with precapillary $\mathrm{PH}$, although

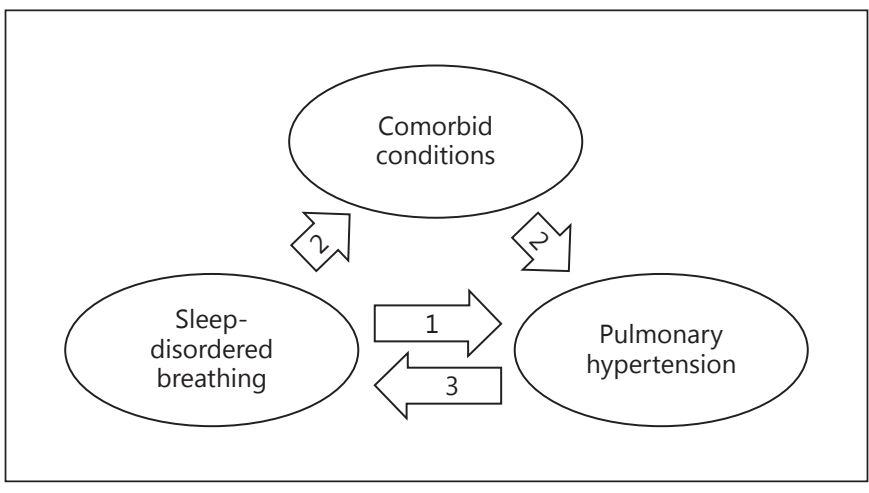

Fig. 1. The interaction between sleep-disordered breathing and precapillary pulmonary hypertension may be mutually mediated by direct effects (arrows labelled 1 and 3) or via comorbid conditions (arrow 2), in particular, chronic respiratory diseases such as chronic obstructive pulmonary disease or obesity hypoventilation syndrome. their relative significance has not been conclusively assessed [13]. Thus, in one study in obese patients with $\mathrm{PH}$ [14], $\mathrm{PaCO}_{2}$ was correlated with PAP; 3 months of treatment with noninvasive ventilation reduced both $\mathrm{PaCO}_{2}$ and PAP. Since $\mathrm{PaO}_{2}$ was also improved, the independent effect of hypercapnia could not be assessed. Nevertheless, other studies in preparations of pulmonary arteries [15], animal models $[16,17]$ and healthy volunteers $[18,19]$ have suggested an independent effect of hypercapnia inducing $\mathrm{PH}$ by pulmonary vasoconstriction through an NO-mediated pathway and by enhanced vasoreactivity of pulmonary arteries. Thus, intermittent sleep-related hypoxemia and hypercapnia alone or in combination with chronic hypoxemia and structural alterations of the lung may predispose to precapillary $\mathrm{PH}$, right ventricular dysfunction and failure. The paucity of conclusive data on this topic may be due to the complexity of measuring pressure and flow in the pulmonary circulation by right heart catheter. Novel echocardiographic and magnetic resonance imaging and other techniques may provide further insights into these interactions in the future [20, 21]. Various pathophysiologic mechanisms linking $\mathrm{PH}$ and SDB will be discussed in the following.

\section{OSA and Precapillary $P H$}

Patients with OSA may show acute or chronic hemodynamic changes associated with intermittent hypoxemia. Various pathophysiologic mechanisms have been discussed. Comorbid conditions additionally play an important role. 


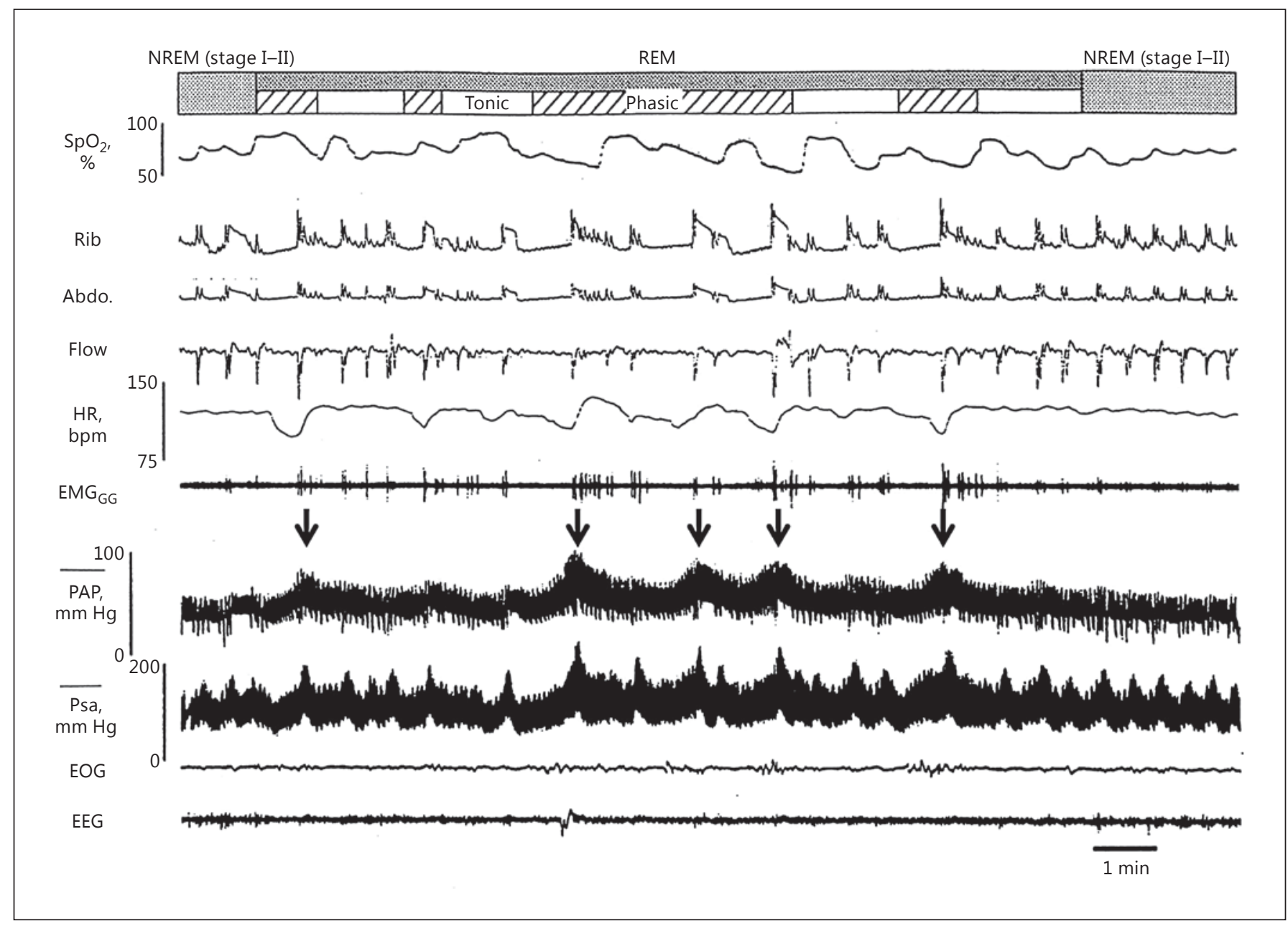

Fig. 2. Example of polysomnographic recording during phasic and tonic rapid eye movement (REM) sleep. There are major rises in both systemic and pulmonary artery pressure (arrows) during ap-

Hypoxic and Hypercapnic Pulmonary Vasoconstriction. Hypoxic pulmonary vasoconstriction is an important mechanism that contributes to maintaining an adequate ventilation-perfusion relationship $(\mathrm{V} / \mathrm{Q})$ in the lungs [22]. Thus, reducing ventilation in a part of the lungs leads to regional hypoxia with vasoconstriction that reduces shunt perfusion. Motley and Cournand [23] showed that breathing a hypoxic gas mixture containing $10 \%$ oxygen induced a rise in PAP. Persistent pulmonary vasoconstriction due to hypoxia may result in vascular remodeling and thus chronic precapillary $\mathrm{PH}$. As outlined above, hypercapnia may also promote pulmonary vasoconstriction in conjunction with or independent of hypoxia. Both hypoxia and hypercapnia are therefore considered to be responsible for the development of pre-

Sleep Apnea and Pulmonary

Hypertension neas in phasic REM sleep (adapted from Niijima et al. [10]). Abdo., abdomen; HR, heart rate; PAP, pulmonary artery pressure; Psa, systemic arterial pressure.

capillary $\mathrm{PH}$ in chronic hypoventilation due to obesity or lung diseases [24]. Some animal studies have suggested that nocturnal intermittent hypoxia in OSA is sufficient to cause persistent daytime $\mathrm{PH}$ und right ventricular dysfunction [25] but this is debated in the case of human OSA. Some studies on this topic included patients with coexisting conditions such as COPD or obesity resulting in sustained hypoxemia by ventilation-perfusion mismatch, diffusion impairment or hypoventilation [26-30], others were performed in sleep apnea patients without comorbidities [31-33]. It is conceivable that patients with chronic lung disease such as COPD that may cause hypoxemia and a reduced pulmonary vascular bed, or patients with hypoxemia due to obesity associated with hypoventilation may be at particular risk to develop pulmo- 
nary vascular remodeling and persistent elevations in $\mathrm{PAP}$ in the presence of aggravated hypoxemia during sleep by OSA.

Sympathetic Overstimulation. In patients with OSA, breathing efforts against an occluded airway cause large fluctuations in systemic blood pressure associated with hypoxemia, arousals and surges of sympathetic tone [34]. Moreover, major rises in both systemic and PAP during long apneas in phasic REM sleep have been described (Fig. 2) [10]. The large arterial pressure swings associated with sympathetic overstimulation in OSA patients induce vascular shear stress and promote endothelial dysfunction [35-37]. Repetitive hypoxia and reoxygenation may upregulate hypoxia-inducible factors, vascular endothelial growth factor and erythropoietin, and trigger inflammatory processes [38]. These mechanisms may lead to elevations in PAP that persist even during daytime and over prolonged time as suggested for the pathophysiology of systemic hypertension in OSA.

Increased Inspiratory Effort. In OSA, the increased inspiratory effort against an occluded airway causes large intrathoracic pressure swings that create mechanical stress on the aorta and the left ventricle and increase afterload contributing to the development of systemic hypertension and cardiovascular disease in affected patients. Acute right ventricular enlargement because of increased venous return may impair left ventricular filling. Together, these mechanisms may lead to an increased pulmonary venous pressure, and postcapillary $\mathrm{PH}$ [39]. Conceivably, similar mechanisms might also lead to elevated PAP. Negative intrathoracic pressure during OSA might additionally cause PAP to rise by increased pulmonary vascular resistance [40]. A similar mechanism has recently been documented in patients with COPD experiencing major increases in pleural pressure swings during exercise that were accompanied by rises in PAP [41].

\section{Precapillary PH and Ventilatory Instability}

Several studies have shown that severe precapillary $\mathrm{PH}$ associated with right ventricular failure and low cardiac output may be associated with SDB including CSR/CSA as well as OSA, similar to what is observed in patients with severe left ventricular failure and postcapillary $\mathrm{PH}[7,42$, 43]. The mechanisms responsible for the destabilizing effect of $\mathrm{PH}$ on control of breathing remain elusive. However, factors that predispose to CSR/CSA in left ventricular failure may also be relevant in right ventricular failure. For example, increased chemosensitivity associated with sympathetic stimulation may promote an overshooting ventilatory response to apneas/hypopneas. Moreover, an excessive circulatory delay due to a reduced cardiac output in severe precapillary $\mathrm{PH}$ may prolong the time required to transport oxygenated blood from the lungs to the chemoreceptors so that the feedback to the respiratory center is desynchronized $[8,44,45]$. Patients with precapillary $\mathrm{PH}$, especially those with right ventricular heart failure and fluid overload, may possibly exhibit nocturnal breathing instability through rostral fluid redistribution at night as suggested by studies in patients with systemic hypertension [46].

\section{Prevalence and Importance of PH in SDB}

There is increasing evidence of an association of SBD with systemic hypertension, incidence of stroke, heart failure, myocardial infarction, arrhythmias and sudden cardiac death [47-49]. Similar data on potentially adverse effects of SDB in patients with $\mathrm{PH}$ are not available. A research of the literature on the prevalence of precapillary $\mathrm{PH}$ in patients with SDB unselected for the absence of comorbidities as well as in patients with concomitant lung and heart diseases has identified the studies summarized in Table 1.

In observational case studies of OSA patients unselected for absence of comorbidities (Table 1, upper part), the prevalence of $\mathrm{PH}$ has varied largely between 17 and $60 \%$ $[27,50]$. When studies excluded patients with coexisting lung and heart diseases, the prevalence of OSA-related $\mathrm{PH}$ was estimated at up to $40 \%$ (Table 1 , lower part) [ 31 , $32,50-52]$; however, in only 2 of these studies $[31,51]$ was the current definition of $\mathrm{PH}$ (mean $\mathrm{PAP}>25 \mathrm{~mm} \mathrm{Hg}$ ) applied. The wide range of prevalence rates may be due to differences in patient selection, disease definition and methodological differences, i.e., invasive pressure measurement with right heart catheter versus Doppler echocardiography. The value and limitations of Doppler echocardiography in the evaluation of $\mathrm{PH}$ patients have been addressed in the recent ESC/ERS guidelines [53]. Additionally, using PAP cutoff values for defining the presence of $\mathrm{PH}$ that are different than the current one (mean PAP $\geq 25 \mathrm{~mm} \mathrm{Hg}$ ) might have confounded the prevalence rates. Data from appropriately powered epidemiologic studies using right heart catheter data and the current definition of $\mathrm{PH}$ are not available to date.

In a large sample of 220 patients with OSA [27], 17\% revealed a mean PAP of $>20 \mathrm{~mm} \mathrm{Hg}$ (i.e., this study used a cutoff for defining $\mathrm{PH}$ that was lower than the mean PAP $\geq 25 \mathrm{~mm} \mathrm{Hg}$ required for the diagnosis of $\mathrm{PH}$ according to current standards). Some of these patients 
Table 1. Pulmonary artery pressure in patients with sleep-disordered breathing

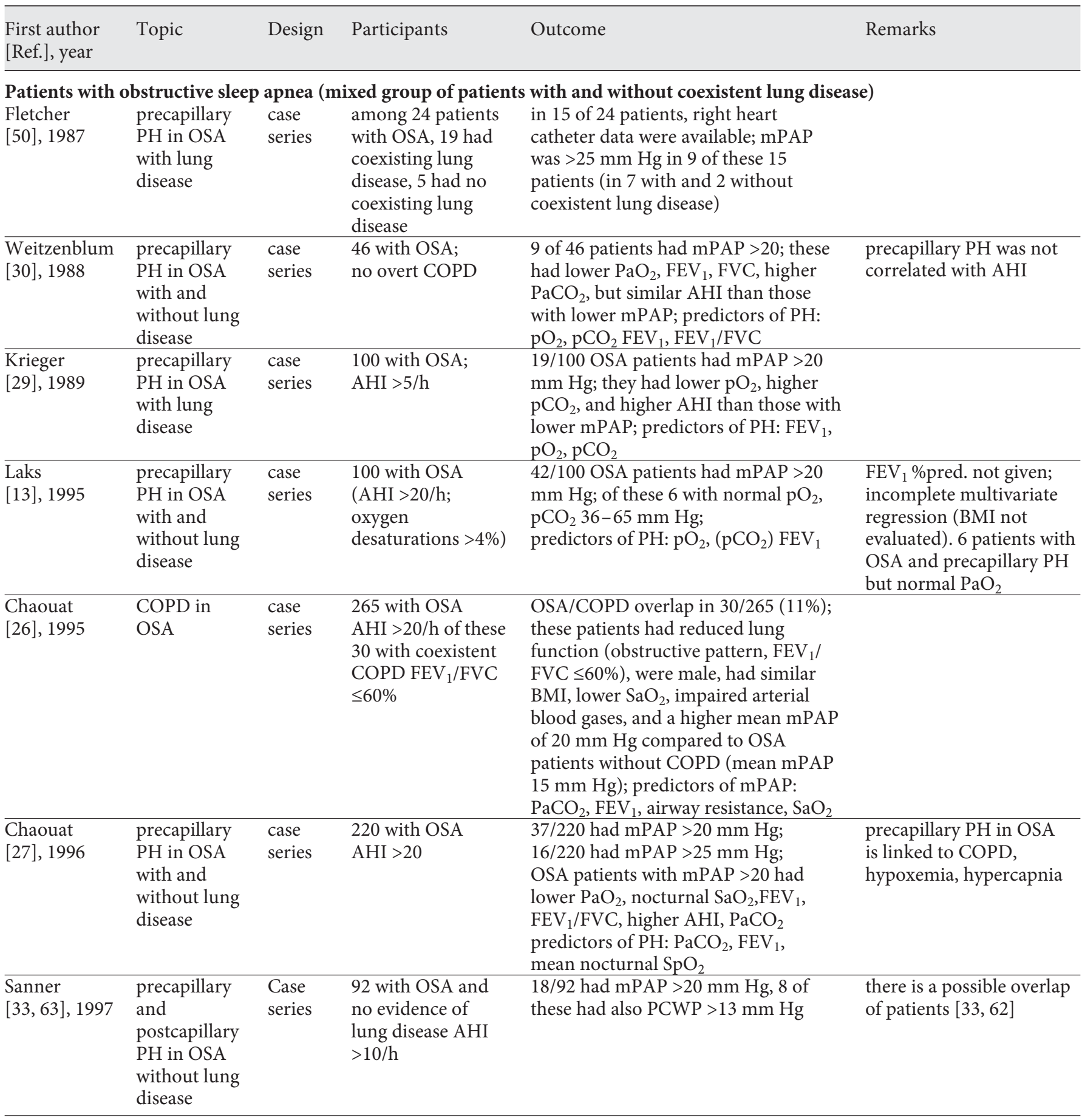


Table 1 (continued)

\begin{tabular}{|c|c|c|c|c|c|}
\hline $\begin{array}{l}\text { First author } \\
\text { [Ref.], year }\end{array}$ & Topic & Design & Participants & Outcome & Remarks \\
\hline \multicolumn{6}{|c|}{ Patients with obstructive sleep apnea without coexistent lung or heart disease } \\
\hline $\begin{array}{l}\text { Fletcher [50], } \\
1987\end{array}$ & $\begin{array}{l}\text { precapillary } \\
\text { PH in OSA } \\
\text { without lung } \\
\text { disease }\end{array}$ & $\begin{array}{l}\text { case } \\
\text { series }\end{array}$ & $\begin{array}{l}\text { among } 24 \text { patients } \\
\text { with OSA, } 5 \text { had } \\
\text { no coexisting lung } \\
\text { disease }\end{array}$ & $\begin{array}{l}2 \text { of } 5 \text { patients had a slightly elevated } \\
\text { mPAP of } 26 \text { and } 27.7 \mathrm{~mm} \mathrm{Hg}\end{array}$ & \\
\hline $\begin{array}{l}\text { Sajkov } \\
{[51], 1994}\end{array}$ & $\begin{array}{l}\text { precapillary } \\
\text { PH in OSA } \\
\text { without lung } \\
\text { disease }\end{array}$ & $\begin{array}{l}\text { case } \\
\text { series }\end{array}$ & $\begin{array}{l}27 \text { patients with } \\
\text { OSA, AHI }>10 / \mathrm{h} \text {, } \\
\text { no lung or heart } \\
\text { disease }\end{array}$ & $\begin{array}{l}11 / 27 \text { patients had mPAP }>20 \text { (range } \\
20-26) \mathrm{mm} \mathrm{Hg} \text {; predictor of mPAP } \\
\text { was } \mathrm{PaO}_{2} \text { only, not pulmonary } \\
\text { function or BMI or AHI }\end{array}$ & $\begin{array}{l}\text { some OSA patients } \\
\text { responded excessively to } \\
\text { hypoxia suggesting } \\
\text { remodeling of pulmonary } \\
\text { vasculature; the cutoff for } \\
\text { PH in this study was } \\
20 \mathrm{~mm} \mathrm{Hg} \text { (not } \geq 25)\end{array}$ \\
\hline $\begin{array}{l}\text { Sajkov } \\
{[52], 1999}\end{array}$ & $\begin{array}{l}\text { precapillary } \\
\text { PH in OSA } \\
\text { without lung } \\
\text { disease }\end{array}$ & $\begin{array}{l}\text { case } \\
\text { series }\end{array}$ & $\begin{array}{l}32 \text { with OSA with } \\
\text { AHI }>10 / \mathrm{h} \text { and } \\
\text { PFT }>80 \% \text { pred., } \\
\text { no cardiac disease }\end{array}$ & $\begin{array}{l}11 / 32 \text { OSA patients had mPAP }>20 \\
\text { mm } \mathrm{Hg} \text { (range } 20-31 \text { ); no difference } \\
\text { in pulmonary function or BMI } \\
\text { between groups; isocapnic hypoxia } \\
\text { with } \mathrm{SpO}_{2} 80 \% \text { induced a greater rise } \\
\text { in mPAP in those with mPAP }>20 \\
\text { mm Hg at baseline; hyperoxia reduced } \\
\text { mPAP more in patients with mPAP } \\
<20 \text { mm Hg at baseline; dobutamin } \\
\text { infusion increased mPAP more in } \\
\text { patients with mPAP }>20 \text { mm Hg at } \\
\text { baseline than in remaining patients; } \\
\text { mPAP was correlated with airway } \\
\text { closure during tidal breathing }\end{array}$ & $\begin{array}{l}\text { some OSA with normal } \\
\text { lung function and no } \\
\text { cardiac disease may have } \\
\text { mild precapillary PH; the } \\
\text { cutoff for PH in this study } \\
\text { was } 20 \mathrm{~mm} \mathrm{Hg} \\
\text { (not } \geq 25 \mathrm{~mm} \mathrm{Hg} \text { ) }\end{array}$ \\
\hline $\begin{array}{l}\text { Bady } \\
{[32], 2000}\end{array}$ & $\begin{array}{l}\text { precapillary } \\
\mathrm{PH} \text { in OSA } \\
\text { without lung } \\
\text { disease }\end{array}$ & $\begin{array}{l}\text { case } \\
\text { series }\end{array}$ & $\begin{array}{l}44 \text { with OSA } \\
(\mathrm{AHI}>5 / \mathrm{h}) \\
\text { normal pulmonary } \\
\text { function }\left(\mathrm{FEV}_{1}\right. \\
>70 \%, \mathrm{FEV}_{1} / \mathrm{FVC} \\
>60 \%)\end{array}$ & $\begin{array}{l}\mathrm{mPAP}>20 \mathrm{~mm} \mathrm{Hg}, \mathrm{PCWP}<15 \mathrm{~mm} \\
\mathrm{Hg} \text { in } 12 / 44 \text { OSA patients without } \\
\text { lung disease; } \mathrm{AHI} \text { in OSA with and } \\
\text { without mPAP }>20 \mathrm{~mm} \mathrm{Hg} \text { was not } \\
\text { different; predictors of } \mathrm{mPAP}^{\mathrm{PaO}}{ }_{2} \text {, } \\
\mathrm{PaCO}_{2} \text {, nocturnal } \mathrm{SpO}_{2} \text {, higher } \mathrm{BMI}\end{array}$ & $\begin{array}{l}\text { no patients with lung } \\
\text { disease. } \mathrm{mPAP} \text { related to } \\
\mathrm{BMI} \text { and } \mathrm{pO}_{2} \text {, not } \mathrm{AHI} \text {; } \\
\text { the cutoff for } \mathrm{PH} \text { in this } \\
\text { study was } 20 \mathrm{~mm} \mathrm{Hg} \\
\text { (not } \geq 25 \mathrm{~mm} \mathrm{Hg} \text { ) }\end{array}$ \\
\hline $\begin{array}{l}\text { Alchanatis } \\
{[31], 2001}\end{array}$ & $\begin{array}{l}\text { precapillary } \\
\text { PH in OSAS, } \\
\text { effect of } \\
\text { CPAP }\end{array}$ & $\begin{array}{l}\text { case } \\
\text { control } \\
\text { study, } \\
\text { before } \\
\text { after } \\
\text { CPAP }\end{array}$ & $\begin{array}{l}29 \text { OSA patients } \\
\text { with AHI }>15 / \mathrm{h} \text { : in } \\
19 \text { of these right } \\
\text { heart catheter data } \\
\text { were shown }\end{array}$ & $\begin{array}{l}3 / 19 \text { of OSA patients had mPAP } \geq 25 \\
\text { mm } \mathrm{Hg} ; \mathrm{mPAP} \text { was correlated with } \\
\text { age, } \mathrm{PaO}_{2}, \mathrm{BMI}\end{array}$ & \\
\hline
\end{tabular}

Several studies used definitions of precapillary pulmonary hypertension (PH) that are not consistent with the current definition of $\mathrm{mPAP} \geq 25 \mathrm{~mm} \mathrm{Hg}$ and PCWP $<15 \mathrm{~mm} \mathrm{Hg}$, the criteria for PH are indicated for individual studies. OSA, obstructive sleep apnea; COPD, chronic obstructive pulmonary disease; MPAP, mean pulmonary artery pressure; AHI, apnea/hypopnea index; BMI, body mass index; CTEPH, chronic thromboembolic pulmonary hypertension; CSR, Cheyne-Stokes respiration; PFT, pulmonary function testing; SDB, sleep-disordered breathing; CPAP, nocturnal continuous positive airway pressure treatment; PCWP, pulmonary capillary wedge pressure.

seem to have suffered from COPD. Laks et al. [13] studied a heterogeneous group of 100 patients with OSA. The mean daytime PAP was $21 \mathrm{~mm} \mathrm{Hg}$ and the apnea/hypopnea index (AHI) varied between 20 and 100 events/h. Forty-two patients had a mean PAP $>20 \mathrm{~mm} \mathrm{Hg}$ (a definition of $\mathrm{PH}$ different from current standards). Several patients were hypoxemic and hypercapnic during daytime and some had impaired pulmonary function suggesting coexisting COPD. In addition, some patients were very obese; $\mathrm{PaO}_{2}, \mathrm{PaCO}_{2}$ and $\mathrm{FEV}_{1}$ explained $33 \%$ of the variation in PAP suggesting that the high prevalence of precapillary $\mathrm{PH}$ of $42 \%$ in this cohort may have been re- 

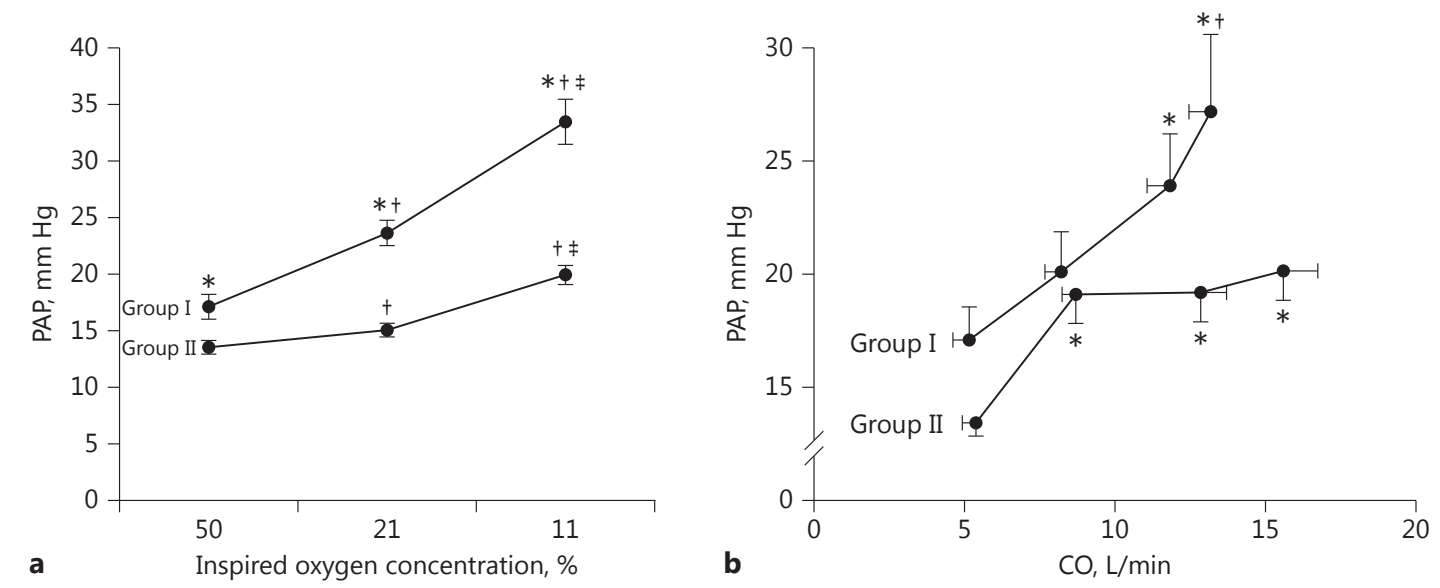

Fig. 3. a Evaluation of hypoxic pulmonary vasoreactivity by exposing patients with obstructive sleep apnea to an $\mathrm{FiO}_{2}$ of 11,21 and $50 \%$. Patients with a mean pulmonary artery pressure (PAP) of $>20$ $\mathrm{mm} \mathrm{Hg}$ at baseline on room air had a brisker response to changes in $\mathrm{FiO}_{2}$ than patients with a mean pulmonary artery pressure $\leq 20$ $\mathrm{mm} \mathrm{Hg}$ suggesting an exaggerated hypoxic response of the pulmonary vasculature of patients with initially higher pulmonary artery

lated to coexistent disorders and to the liberal PH definition of mean PAP $>20 \mathrm{~mm} \mathrm{Hg}$ at that time.

Sajkov et al. [51] compared a group of OSA patients with mildly elevated PAP still within the normal range (mean PAP of $22.8 \mathrm{~mm} \mathrm{Hg}$ ) with another group of patients with a similar degree of OSA but low normal PAP (mean PAP of $14.6 \mathrm{~mm} \mathrm{Hg}$ ). In both groups, no heart or lung disease could be found even by detailed examinations, but the patients with higher PAP had lower $\mathrm{PaO}_{2}$. The authors speculated that these patients had an excessive hypoxic response of the pulmonary vasculature that promoted the development of $\mathrm{PH}$ in combination with OSA.

To further corroborate the mechanisms involved in the rise of PAP in certain patients with OSA, Sajkov et al. [52] studied 32 OSA patients without any evidence of cardiac or pulmonary disease. Eleven of them had a mean $\mathrm{PAP}>20 \mathrm{~mm} \mathrm{Hg}$ but a similar AHI, body mass index and daytime arterial blood gas values as the remainder of the patients with a mean PAP $<20 \mathrm{~mm} \mathrm{Hg}$. Although both groups of OSA patients had normal spirometry, the patients with higher mean PAP had a reduced closing volume measured by the nitrogen washout technique. The difference between functional residual capacity and closing volume was negative indicating that some patients ex-

perienced intermittent closure of peripheral airways during tidal breathing. This might have predisposed them to a V/Q mismatch and hypoxemia thereby contributing to elevated PAP. In the same group of OSA patients, Sajkov et al. [52] evaluated the hypoxic pulmonary vasoreactivity by exposing patients to an inspiratory fraction of oxygen $\left(\mathrm{FiO}_{2}\right)$ of 11,21 and $50 \%$ while PAP was monitored. Patients with elevated PAP at baseline on room air above $20 \mathrm{~mm} \mathrm{Hg}$ had a brisker response to changes in $\mathrm{FiO}_{2}$ than patients with lower baseline mean PAP. In addition, challenges with dobutamin infusion were performed. With increases in cardiac output, PAP rose significantly more in patients with mean PAP $>20 \mathrm{~mm} \mathrm{Hg}$ at baseline compared to the rest of the patients. These findings were considered to be consistent with vascular remodeling in some of the OSA patients [52] (Fig. 3).

\section{SDB in Patients with Precapillary PH}

So far, the direct or indirect effects of SDB on precapillary $\mathrm{PH}$ had been discussed. There is evidence that the relation may also act in the opposite direction, so that precapillary $\mathrm{PH}$ may trigger SDB (Fig. 1). As many features of patients with left ventricular failure and SDB, 
Table 2. Sleep-disordered breathing among patients with precapillary pulmonary hypertension

\begin{tabular}{|c|c|c|c|c|c|}
\hline $\begin{array}{l}\text { First author } \\
\text { [Ref.], year }\end{array}$ & Topic & Design & Participants & Outcome & Remarks \\
\hline $\begin{array}{l}\text { Rafanan } \\
{[56], 2001}\end{array}$ & $\begin{array}{l}\text { Nocturnal } \\
\text { hypoxemia in } \\
\text { precapillary } \mathrm{PH}\end{array}$ & $\begin{array}{l}\text { case } \\
\text { series }\end{array}$ & 13 with $\mathrm{PAH}$ & $\begin{array}{l}\text { 10/13 were nocturnal desaturators, i.e., } \\
>10 \% \text { of nighttime with } \mathrm{SpO}_{2}<90 \% \text {; } \\
\text { desaturators had lower } \mathrm{FEV}_{1} \text { and } \mathrm{PaO}_{2} \text {, } \\
\text { higher hemoglobin concentration }\end{array}$ & \\
\hline $\begin{array}{l}\text { Schulz } \\
{[54], 2002}\end{array}$ & $\begin{array}{l}\text { CSR in precapillary } \\
\mathrm{PH}\end{array}$ & $\begin{array}{l}\text { case } \\
\text { series }\end{array}$ & 20 with PAH & $\begin{array}{l}\text { CSR in } 6 / 20 \text { who had more severe pre- } \\
\text { capillary } \mathrm{PH} \text {; nasal oxygen eliminated } \\
\text { CSR }\end{array}$ & $\begin{array}{l}\text { suggests effect } \\
\text { of oxygen }\end{array}$ \\
\hline $\begin{array}{l}\text { Schulz } \\
{[64], 2004}\end{array}$ & $\begin{array}{l}\text { CSR in precapillary } \\
\mathrm{PH}\end{array}$ & $\begin{array}{l}\text { case } \\
\text { report }\end{array}$ & 1 female with $\mathrm{PAH}$ & $\begin{array}{l}\text { polysomnography before and after } \\
\text { lung transplantation shows } \\
\text { disappearance of CSR }\end{array}$ & \\
\hline $\begin{array}{l}\text { Minai } \\
{[55], 2007}\end{array}$ & $\begin{array}{l}\text { nocturnal } \\
\text { hypoxemia in } \\
\text { precapillary } \mathrm{PH}\end{array}$ & $\begin{array}{l}\text { case } \\
\text { series }\end{array}$ & 43 with $\mathrm{PAH}$ & $\begin{array}{l}30 / 43 \text { were desaturators with }>10 \% \text { of } \\
\text { the night-time with } \mathrm{SpO}_{2}<90 \% \text {; } \\
\text { desaturators had higher hemoglobin, } \\
\text { higher brain natriuretic peptide, higher } \\
\text { mPAP, lower cardiac index }\end{array}$ & \\
\hline $\begin{array}{l}\text { Prisco } \\
{[43], 2011}\end{array}$ & $\begin{array}{l}\text { SDB in precapillary } \\
\mathrm{PH}\end{array}$ & $\begin{array}{l}\text { case } \\
\text { series }\end{array}$ & $\begin{array}{l}28 \text { with precapillary } \\
\text { PH (PAH 9, associated } \\
\text { PH } 21\end{array}$ & $\begin{array}{l}\text { precapillary } \mathrm{PH} \text { severity best correlated } \\
\text { with combination of } \mathrm{AHI} \text { and time of } \\
\text { the night spent with } \mathrm{SpO}_{2}<90 \%\end{array}$ & \\
\hline $\begin{array}{l}\text { Hildenbrand } \\
{[65], 2012}\end{array}$ & $\begin{array}{l}\text { nocturnal } \\
\text { hypoxemia in PAH, } \\
\text { CTEPH }\end{array}$ & $\begin{array}{l}\text { case } \\
\text { series }\end{array}$ & $\begin{array}{l}63 \text { with precapillary } \\
\text { PH ( } 44 \text { PAH, } \\
19 \text { CTEPH) }\end{array}$ & $\begin{array}{l}77 \% \text { spent }>10 \% \text { of the nighttime with } \\
\mathrm{SpO}_{2}<90 \%\end{array}$ & \\
\hline $\begin{array}{l}\text { Jilwan } \\
{[42], 2013}\end{array}$ & $\begin{array}{l}\text { SDB in PAH, } \\
\text { CTEPH }\end{array}$ & $\begin{array}{l}\text { case } \\
\text { series }\end{array}$ & $\begin{array}{l}46 \text { with precapillary } \\
\text { PH (29 PAH, } \\
17 \text { CTEPH) }\end{array}$ & $\begin{array}{l}89 \% \text { had sleep apnea, } \\
83 \% \text { had nighttime hypoxemia }\end{array}$ & $\begin{array}{l}\mathrm{BMI}<35 \\
\mathrm{FEV}_{1}>60 \%\end{array}$ \\
\hline $\begin{array}{l}\text { Dumitrascu } \\
{[66], 2013}\end{array}$ & $\begin{array}{l}\text { SDB in various } \\
\text { forms of pre- } \\
\text { capillary PH }\end{array}$ & $\begin{array}{l}\text { case } \\
\text { series }\end{array}$ & $\begin{array}{l}169 \text { with precapillary } \\
\text { PH ( } 28 \text { PAH, } \\
51 \text { CTEPH, } 16 \text { colla- } \\
\text { gen vascular disease, } \\
59 \text { chronic lung disease, } \\
15 \text { other) }\end{array}$ & $\begin{array}{l}26.6 \% \text { had sleep apnea, } \\
\text { AHI }>10 / \text { h, of these } 16.0 \% \text { had OSA, } \\
10.6 \% \text { had CSA }\end{array}$ & \\
\hline
\end{tabular}

$\mathrm{PH}$, pulmonary hypertension; $\mathrm{PAH}$, pulmonary arterial hypertension; CSR, Cheyne-Stokes respiration; CTEPH, chronic thromboembolic pulmonary hypertension; $\mathrm{mPAP}$, mean pulmonary artery pressure; SDB, sleep disordered breathing; OSA, obstructive sleep apnea; AHI, apnea/hypopnea index; BMI, body mass index

such as low cardiac output, increased sympathetic tone, and arrhythmia, are also common in patients with precapillary $\mathrm{PH}$ and right ventricular failure, some authors have also looked at SDB in patients with precapillary $\mathrm{PH}$ of different origins. These studies are summarized in Table 2.

Schulz et al. [54] were the first to describe CSR/CSA in patients with pulmonary arterial hypertension (PAH; WHO class I). Patients had typical periodic breathing with waxing and waning of ventilation. Fourteen had an AHI of $<20 /$ h and 6 had an AHI $>20 /$ h with nearly exclusively central events consistent with CSR/CSA. In order to further evaluate the prevalence and type of sleep-related breathing disturbances in $\mathrm{PH}$ patients, we performed a prospective study in consecutive patients with either $\mathrm{PAH}$ or chronic thromboembolic pulmonary hypertension [7]. In none of these patients had SDB been suspected on clinical grounds and most of them had been treated for PAH/chronic thromboembolic pulmonary hypertension with various drugs for several months or years. A total of 38 patients were studied. In Figure 4, the total AHI in each patient and the relation between central and obstructive events are shown. Eighteen patients or $47 \%$ had an elevated AHI of $>10 / \mathrm{h}$. The large majority had pre- 
dominant CSR but 4 patients also had more than $10 \mathrm{ob}-$ structive events per hour. No significant differences in hemodynamics, arterial blood gases or pulmonary function between the groups with and without increased AHI were found. Polysomnography and pulse oximetry were used to assess SDB in the study by Ulrich et al. [7] to evaluate the diagnostic accuracy of the simple technique in this setting. Although pulse oximetry had been proposed as part of the routine evaluation of patients with $\mathrm{PH}$ to detect nighttime hypoxemia [55], oximetry alone revealed a poor diagnostic performance (area under the receiver operating characteristic curve of only $0.66 \pm 0.14$ ) in identifying patients with an $\mathrm{AHI} \geq 10$, when compared with polysomnography [7]. Thus, pulse oximetry alone cannot be recommended as diagnostic tool for SDB in $\mathrm{PH}$ patients. Whereas in some studies on the association of precapillary $\mathrm{PH}$ with SDB nocturnal hypoxemia without sleep apnea was the predominant finding $[55,56]$, others found sleep apnea without severe persistent hypoxemia $[7,54]$ or a combination of both persistent hypoxemia and sleep apnea $[42,43]$. In a most recent study in Kyrgyz highlanders, a high prevalence of mainly OSAs was found among individuals with high-altitude $\mathrm{PH}$, a particular form of precapillary $\mathrm{PH}$ occurring in life-long residents at altitudes $>2,500 \mathrm{~m}$. This observation suggests that individuals exposed to the combined stimuli of chronic hypoxemia due to high-altitude residence and intermittent nocturnal hypoxemia due to sleep apnea may be more susceptible to $\mathrm{PH}$ compared to highlanders without sleep apnea [57].

\section{Treatment of PH in SBD}

Tracheostomy and supplemental oxygen have been shown to reduce PAP in patients with COPD and nighttime hypoxemia [58] but this intervention (tracheostomy) is rarely performed nowadays. Limited data on effects of continuous positive airway pressure (CPAP) treatment in patients with OSA on PAP are available. In a case-control study by Alchanatis et al. [31], 29 patients without evidence of pulmonary or cardiac disease were studied with Doppler echocardiography before and after 6 months of CPAP treatment. Of these 29 patients, 6 had mild precapillary $\mathrm{PH}$. The control group consisted of 12 healthy subjects. Older subjects and those with increased body mass index in the OSA group were more prone to suffer from (generally mild) precapillary $\mathrm{PH}$ and 6 months of CPAP caused a significant fall in PAP in hyper- and normotensive patients pointing to OSA

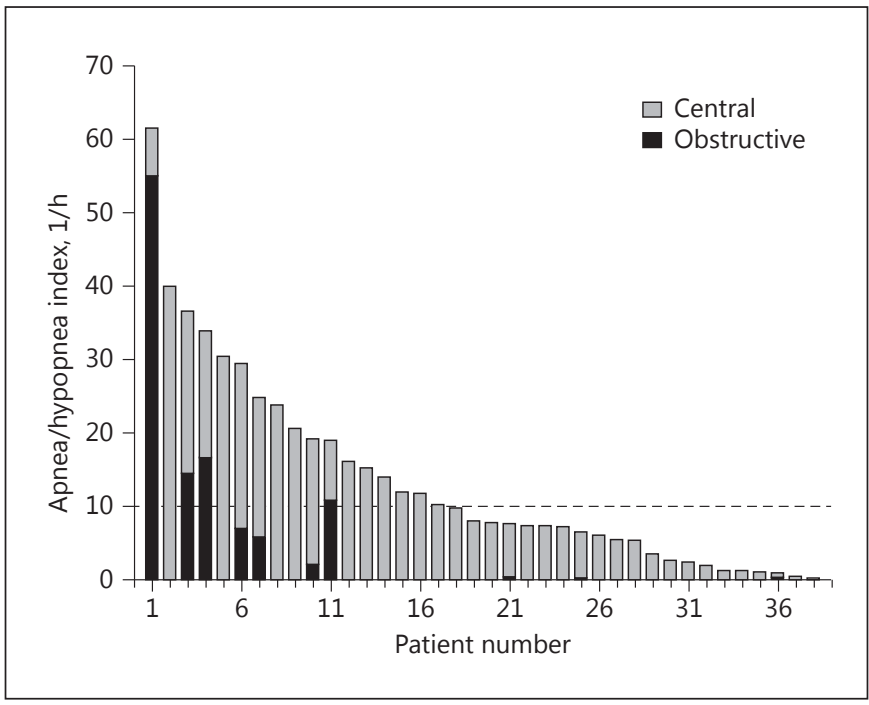

Fig. 4. Apnea/hypopnea index in 38 patients with precapillary pulmonary hypertension. The bars are ordered in descending order of the total apnea/hypopnea index with the black part representing the obstructive and the gray part the central events. A value of $\geq 10$ was observed in $45 \%$ of patients, the median value was $8 / \mathrm{h}$ (reproduced from Ulrich et al. [7]).

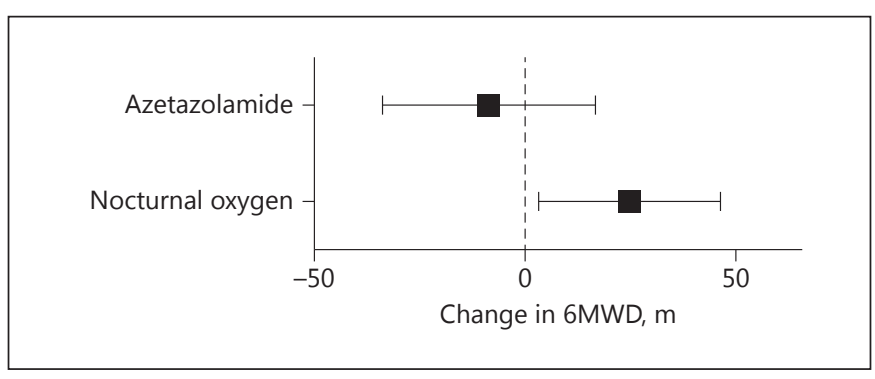

Fig. 5. Results of a randomized, placebo-controlled double-blind trial evaluating the effect of 1 week of nocturnal oxygen therapy and acetazolamide, respectively, on the 6-min walk distance (6MWD) in patients with precapillary pulmonary hypertension and sleep-related breathing disturbances. Mean differences and $95 \%$ confidence intervals of the 6 -min walk distance between acetazolamide and placebo and between oxygen and sham oxygen (ambient air) are shown (reproduced from Ulrich et al. [62]).

as an independent risk factor for the development of precapillary $\mathrm{PH}$. In another study including patients with moderate to severe OSA, 4 months of CPAP significantly reduced the PAP, especially when the PAP was elevated at baseline [59]. Moreover, the pulmonary vascular response to hypoxia decreased after CPAP treatment [59]. In a randomized crossover trial in patients with OSA using sham or effective CPAP for 12 
Table 3. Interventional studies in patients with precapillary pulmonary hypertension and sleep apnea

\begin{tabular}{|c|c|c|c|c|c|}
\hline $\begin{array}{l}\text { First author } \\
\text { [Ref.], year }\end{array}$ & Topic & Design & Participants & Outcome & Remarks \\
\hline $\begin{array}{l}\text { Alchanatis } \\
{[31], 2001}\end{array}$ & $\begin{array}{l}\text { precapillary } \mathrm{PH} \\
\text { in OSAS, effect } \\
\text { of CPAP }\end{array}$ & $\begin{array}{l}\text { case control } \\
\text { study, before } \\
\text { after CPAP }\end{array}$ & $\begin{array}{l}33 \text { with OSA AHI } \\
>15 / \mathrm{h}: 29 \text { with } \\
\text { OSA } \\
\text { at baseline and } \\
\text { after CPAP, } 12 \\
\text { snorers }\end{array}$ & $\begin{array}{l}\text { OSA patients had higher mPAP } \\
\text { than controls; } 3 / 19 \text { OSA had } \\
\text { mPAP }>25 \mathrm{~mm} \mathrm{Hg} ; \mathrm{mPAP} \text { was } \\
\text { correlated with age, } \mathrm{PaO}_{2} \text {, BMI. } \\
\text { CPAP reduced mPAP in all OSA } \\
\text { patients (see also Table } 1 \text { ) }\end{array}$ & $\begin{array}{l}\text { baseline assessment } \\
\text { by right heart } \\
\text { catheterization, } \\
\text { follow-up assessment } \\
\text { of PAP by } \\
\text { echocardiography }\end{array}$ \\
\hline $\begin{array}{l}\text { Sajkov } \\
{[59], 2002}\end{array}$ & $\begin{array}{l}\text { precapillary } \mathrm{PH} \\
\text { in OSAS, effect } \\
\text { of CPAP }\end{array}$ & $\begin{array}{l}\text { observational } \\
\text { study on CPAP } \\
\text { effect on } \\
\text { precapillary } \\
\text { PH in OSA } \\
\text { without lung } \\
\text { disease }\end{array}$ & $\begin{array}{l}20 \text { with OSA of } 32 \\
\text { OSA with AHI }>10 \\
\text { and pulmonary } \\
\text { function variables } \\
>80 \% \text { predicted, } \\
\text { no cardiac disease }\end{array}$ & $\begin{array}{l}5 / 20 \text { OSA had mPAP }>20 \mathrm{~mm} \\
\text { Hg; sPAP was reduced in all } \\
\text { patients after } 4 \text { months of CPAP } \\
\text { except in } 1 \text { non-compliant } \\
\text { patient; hypoxic vasoreactivity } \\
\text { was reduced and flow response } \\
\text { was shifted downward in a } \\
\text { parallel fashion; systemic blood } \\
\text { pressure was also reduced }\end{array}$ & $\begin{array}{l}\text { results may suggest } \\
\text { that PAP was reduced } \\
\text { because of improved } \\
\text { endothelial function } \\
\text { and possibly reverse } \\
\text { remodeling in some } \\
\text { patients. }\end{array}$ \\
\hline $\begin{array}{l}\text { Colish } \\
{[67], 2012}\end{array}$ & $\begin{array}{l}\text { precapillary } \mathrm{PH} \\
\text { in OSA and } \\
\text { CPAP }\end{array}$ & $\begin{array}{l}\text { observational, } \\
\text { prospective } \\
\text { study on one- } \\
\text { year treatment } \\
\text { effects }\end{array}$ & $\begin{array}{l}47 \text { OSA, } \\
\text { AHI } 63 \pm 30 / h\end{array}$ & $\begin{array}{l}\text { s PAP decreased significantly } \\
\text { from } 54 \text { to } 39 \mathrm{~mm} \mathrm{Hg}\end{array}$ & \\
\hline $\begin{array}{l}\text { Ulrich } \\
{[62], 2015}\end{array}$ & $\begin{array}{l}\text { precapillary } \mathrm{PH} \\
\text { and SBD; effect } \\
\text { of nocturnal } \\
\text { oxygen vs. } \\
\text { placebo and vs. } \\
\text { acetazolamide }\end{array}$ & $\begin{array}{l}\text { randomized, } \\
\text { double-blind } \\
\text { double } \\
\text { crossover }\end{array}$ & $\begin{array}{l}23 \text { patients, with } \\
\text { precapillary } \mathrm{PH} \text {; } \\
16 \mathrm{PAH}, 7 \mathrm{CTEPH}\end{array}$ & $\begin{array}{l}\text { oxygen improved 6-min walk } \\
\text { distance after } 1 \text { week of treatment, } \\
\text { acetazolamide had no } \\
\text { significant effect compared to } \\
\text { placebo. Both oxygen and } \\
\text { acetazolamide improved the } \\
\text { AHI and nocturnal oxygenation; } \\
\text { sPAP did not change with any } \\
\text { of the treatments }\end{array}$ & $\begin{array}{l}\text { nocturnal oxygen } \\
\text { therapy also improved } \\
\text { nocturnal } \\
\text { oxygenation, periodic } \\
\text { breathing, functional } \\
\text { class and indices right } \\
\text { ventricular function }\end{array}$ \\
\hline
\end{tabular}

$\mathrm{PH}$, pulmonary hypertension; OSA(S), obstructive sleep apnea (syndrome); CPAP, continuous positive airway pressure; AHI, apnea/ hypopnea index; mPAP, sPAP, mean and systolic pulmonary artery pressure estimated by echocardiography; BMI, body mass index; $\mathrm{BP}$, blood pressure; CTEPH, chronic thromboembolic pulmonary hypertension; PAH, pulmonary arterial hypertension; SDB, sleep disordered breathing; UPPP, uvulopalatopharyngoplasty.

weeks, PAP was reduced significantly by CPAP [60]. The studies mentioned above have not included right heart catheter data to demonstrate whether improvement in pulmonary hemodynamics occurred because of improvement in precapillary $\mathrm{PH}$ or by improving left ventricular function.
Supplemental nocturnal oxygen has been used in patients with nocturnal hypoxemia-related $\mathrm{PH}$. In COPD patients, long-term home oxygen therapy did not improve survival in patients with mild to moderate hypoxemia or in those with arterial desaturation at night only [61]. It is uncertain whether this also applies to $\mathrm{PH}$ pa- 
tients with nighttime hypoxemia and SBD. In the only randomized, placebo-controlled study in patients with precapillary $\mathrm{PH}$ and SDB nocturnal oxygen therapy improved the 6-min walk distance already after 1 week (Fig. 5) and reduced the AHI [62]. In turn, acetazolamide $(2 \times 250 \mathrm{mg}$ tablets/day) reduced the AHI to a similar degree but did not change the 6-min walk distance [62]. Whether selected patients with PAH and SDB may benefit from specific $\mathrm{PH}$ therapy has not been studied. Table 3 gives an overview of interventional studies with CPAP or oxygen in patients with SBD associated precapillary PH.

\section{Conclusions}

Available data suggest that about one half of patients with OSA unselected for the absence of comorbidities have intermittent or sustained elevations of the PAP and that up to one half of patients with precapillary $\mathrm{PH}$ suffer from SBD. Several pathophysiologic mechanisms predispose patients with SBD to precapillary $\mathrm{PH}$. However, precapillary $\mathrm{PH}$ in OSA not associated with any other conditions leading to hypoxemia seems to be rare. Optimized therapy of any comorbidity such as COPD and obesity seems to be crucial. For the remaining patients with both SDB and PH but without comorbidity, positive pressure ventilation or oxygen might be beneficial in terms of lowering the PAP but this has not been evaluated in rigorous randomized trials. In patients with precapillary PH associated with SDB nocturnal oxygen supplementation has improved exercise performance and SDB in one trial [62] but long-term studies that confirm these findings are lacking. The role of CPAP or other modes of positive pressure ventilation and of $\mathrm{PH}$ specific drugs in the treatment of patients with precapillary $\mathrm{PH}$ and central or OSA requires further evaluation in randomized trials.

\section{Acknowledgement}

This study was funded by the Zurich Lung League, and the Clinical Research Priority Program Sleep and Health University of Zurich, Switzerland.

\section{References}

1 Shetty S, Parthasarathy S: Obesity hypoventilation syndrome. Curr Pulmonol Rep 2015;4: $42-55$.

-2 Leon-Velarde F, Maggiorini M, Reeves JT, Aldashev A, Asmus I, Bernardi L, Ge RL, Hackett P, Kobayashi T, Moore LG, Penaloza D, Richalet JP, Roach R, Wu T, Vargas E, Zubieta-Castillo G, Zubieta-Calleja G: Consensus statement on chronic and subacute high altitude diseases. High Alt Med Biol 2005;6:147157.

-3 Young T, Palta M, Dempsey J, Skatrud J, Weber S, Badr S: The occurrence of sleep-disordered breathing among middle-aged adults. N Engl J Med 1993;328:1230-1235.

4 Young T, Peppard PE, Gottlieb DJ: Epidemiology of obstructive sleep apnea: a population health perspective. Am J Respir Crit Care Med 2002;165:1217-1239.

5 Heinzer R, Vat S, Marques-Vidal P, MartiSoler H, Andries D, Tobback N, Mooser V, Preisig M, Malhotra A, Waeber G, Vollenweider P, Tafti M, Haba-Rubio J: Prevalence of sleep-disordered breathing in the general population: the HypnoLaus study. Lancet Respir Med 2015;3:310-318.

-6 Ismail K, Roberts K, Manning P, Manley C, Hill NS: OSA and pulmonary hypertension: time for a new look. Chest 2015;147:847-861.

Sleep Apnea and Pulmonary

Hypertension
7 Ulrich S, Fischler M, Speich R, Bloch KE: Sleep-related breathing disorders in patients with pulmonary hypertension. Chest 2008; 133:1375-1380

$\checkmark 8$ Brack T, Randerath W, Bloch KE: CheyneStokes respiration in patients with heart failure: prevalence, causes, consequences and treatments. Respiration 2012;83:165-176.

-9 Veerman DP, Imholz BP, Wieling W, Wesseling KH, van Montfrans GA: Circadian profile of systemic hemodynamics. Hypertension 1995;26:55-59.

10 Niijima M, Kimura H, Edo H, Shinozaki T, Kang J, Masuyama S, Tatsumi K, Kuriyama T: Manifestation of pulmonary hypertension during REM sleep in obstructive sleep apnea syndrome. Am J Respir Crit Care Med 1999; 159:1766-1772.

-11 Raeside DA, Brown A, Patel KR, Welsh D, Peacock AJ: Ambulatory pulmonary artery pressure monitoring during sleep and exercise in normal individuals and patients with COPD. Thorax 2002;57:1050-1053.

12 Minic M, Granton JT, Ryan CM: Sleep disordered breathing in group 1 pulmonary arterial hypertension. J Clin Sleep Med 2014;10: 277-283.

13 Laks L, Lehrhaft B, Grunstein RR, Sullivan CE: Pulmonary hypertension in obstructive sleep apnoea. Eur Respir J 1995;8:537-541.
14 Held M, Walthelm J, Baron S, Roth C, Jany B: Functional impact of pulmonary hypertension due to hypoventilation and changes under noninvasive ventilation. Eur Respir J 2014;43:156-165.

15 Vankova M, Snetkov VA, Knock GA, Aaronson PI, Ward JP: Euhydric hypercapnia increases vasoreactivity of rat pulmonary arteries via $\mathrm{HCO}_{3}$ - transport and depolarisation. Cardiovasc Res 2005;65:505-512.

16 Barer GR, Howard P, Shaw JW: Stimulus-response curves for the pulmonary vascular bed to hypoxia and hypercapnia. J Physiol 1970; 211:139-155.

17 Ketabchi F, Egemnazarov B, Schermuly RT, Ghofrani HA, Seeger W, Grimminger F, ShidMoosavi M, Dehghani GA, Weissmann N, Sommer N: Effects of hypercapnia with and without acidosis on hypoxic pulmonary vasoconstriction. Am J Physiol Lung Cell Mol Physiol 2009;297:L977-L983.

18 Dorrington KL, Balanos GM, Talbot NP, Robbins PA: Extent to which pulmonary vascular responses to $\mathrm{PCO}_{2}$ and $\mathrm{PO}_{2}$ play a functional role within the healthy human lung. J Appl Physiol (1985) 2010;108:1084-1096.

19 Kiely DG, Cargill RI, Lipworth BJ: Effects of hypercapnia on hemodynamic, inotropic, lusitropic, and electrophysiologic indices in humans. Chest 1996;109:1215-1221. 
20 Bossone E, D’Andrea A, D’Alto M, Citro R, 34 Dempsey JA, Veasey SC, Morgan BJ, Argiento P, Ferrara F, Cittadini A, Rubenfire M, Naeije R: Echocardiography in pulmonary arterial hypertension: from diagnosis to prognosis. J Am Soc Echocardiogr 2013;26:1-14.

21 Claessen G, La Gerche A, Voigt JU, Dymarkowski S, Schnell F, Petit T, Willems R, Claus P, Delcroix M, Heidbuchel H: Accuracy of echocardiography to evaluate pulmonary vascular and RV function during exercise. JACC Cardiovasc Imaging 2016;9:532-543.

22 Voelkel NF: Mechanisms of hypoxic pulmonary vasoconstriction. Am Rev Respir Dis 1986;133:1186-1195.

23 Motley HL, Cournand A: The influence of short periods of induced acute anoxia upon pulmonary artery pressures in man. Am Physiol 1947;150:315-320.

24 Moudgil R, Michelakis ED, Archer SL: Hypoxic pulmonary vasoconstriction. J Appl Physiol (1985) 2005;98:390-403.

25 Nattie EE, Bartlett D Jr, Johnson K: Pulmonary hypertension and right ventricular hypertrophy caused by intermittent hypoxia and hypercapnia in the rat. Am Rev Respir Dis 1978;118:653-658.

-26 Chaouat A, Weitzenblum E, Krieger J, Ifoundza T, Oswald M, Kessler R: Association of chronic obstructive pulmonary disease and sleep apnea syndrome. Am J Respir Crit Care Med 1995;151:82-86.

27 Chaouat A, Weitzenblum E, Krieger J, Oswald M, Kessler R: Pulmonary hemodynamics in the obstructive sleep apnea syndrome. Results in 220 consecutive patients. Chest 1996;109:380-386.

28 Chaouat A, Naeije R, Weitzenblum E: Pulmonary hypertension in COPD. Eur Respir 2008;32:1371-1385.

-29 Krieger J, Sforza E, Apprill M, Lampert E, Weitzenblum E, Ratomaharo J: Pulmonary hypertension, hypoxemia, and hypercapnia in obstructive sleep apnea patients. Chest 1989;96:729-737.

30 Weitzenblum E, Krieger J, Apprill M, Vallee E, Ehrhart M, Ratomaharo J, Oswald M, Kurtz D: Daytime pulmonary hypertension in patients with obstructive sleep apnea syndrome. Am Rev Respir Dis 1988;138:345 349.

- 31 Alchanatis M, Tourkohoriti G, Kakouros S, Kosmas E, Podaras S, Jordanoglou JB: Daytime pulmonary hypertension in patients with obstructive sleep apnea: the effect of continuous positive airway pressure on pulmonary hemodynamics. Respiration 2001;68 566-572.

-32 Bady E, Achkar A, Pascal S, Orvoen-Frija E, Laaban JP: Pulmonary arterial hypertension in patients with sleep apnoea syndrome. Tho$\operatorname{rax}$ 2000;55:934-939.

-33 Sanner BM, Doberauer C, Konermann M, Sturm A, Zidek W: Pulmonary hypertension in patients with obstructive sleep apnea syndrome. Arch Intern Med 1997;157:24832487.
O'Donnell CP: Pathophysiology of sleep apnea. Physiol Rev 2010;90:47-112.

35 Kohler M, Stradling JR: Mechanisms of vascular damage in obstructive sleep apnea. Nat Rev Cardiol 2010;7:677-685.

36 Szulcek R, Happe CM, Rol N, Fontijn RD, Dickhoff C, Hartemink KJ, Grunberg K, Tu L, Timens W, Nossent GD, Paul MA, Leyen TA, Horrevoets AJ, de Man FS, Guignabert C, Yu PB, Vonk-Noordegraaf A, van Nieuw Amerongen GP, Bogaard HJ: Delayed microvascular shear adaptation in pulmonary arterial hypertension. Role of platelet endothelial cell adhesion molecule-1 cleavage. Am J Respir Crit Care Med 2016;193:1410-1420.

37 Dickinson MG, Bartelds B, Borgdorff MA, Berger RM: The role of disturbed blood flow in the development of pulmonary arterial hypertension: lessons from preclinical animal models. Am J Physiol Lung Cell Mol Physiol 2013;305:L1-L14.

38 Ryan S, Taylor CT, McNicholas WT: Selective activation of inflammatory pathways by intermittent hypoxia in obstructive sleep apnea syndrome. Circulation 2005;112:2660-2667.

39 Buda AJ, Schroeder JS, Guilleminault C: Abnormalities of pulmonary artery wedge pressures in sleep-induced apnea. Int J Cardiol 1981;1:67-74.

-40 Podszus T, Bauer W, Mayer J, Penzel T, Peter $\mathrm{JH}$, von Wichert P: Sleep apnea and pulmonary hypertension. Klin Wochenschr 1986; 64:131-134.

41 Naeije R, Boerrigter BG: Pulmonary hypertension at exercise in COPD: does it matter? Eur Respir J 2013;41:1002-1004.

42 Jilwan FN, Escourrou P, Garcia G, Jais X, Humbert M, Roisman G: High occurrence of hypoxemic sleep respiratory disorders in precapillary pulmonary hypertension and mechanisms. Chest 2013;143:47-55.

43 Prisco DL, Sica AL, Talwar A, Narasimhan M, Omonuwa K, Hakimisefat B, Dedopoulos S, Shakir N, Greenberg H: Correlation of pulmonary hypertension severity with metrics of comorbid sleep-disordered breathing. Sleep Breath 2011;15:633-639.

44 Bradley TD, Floras JS: Sleep apnea and heart failure. Part II: central sleep apnea. Circulation 2003; 107:1822-1826.

45 Brack T, Thuer I, Clarenbach CF, Senn O, Noll G, Russi EW, Bloch KE: Daytime Cheyne-Stokes respiration in ambulatory patients with severe congestive heart failure is associated with increased mortality. Chest 2007;132:1463-1471.

46 Friedman O, Bradley TD, Chan CT, Parkes R, Logan AG: Relationship between overnight rostral fluid shift and obstructive sleep apnea in drug-resistant hypertension. Hypertension 2010;56:1077-1082.

47 Thurnheer R: Obstructive sleep apnea and cardiovascular disease - time to act! Swiss Med Wkly 2007;137:217-222.
48 Yaggi HK, Concato J, Kernan WN, Lichtman $\mathrm{JH}$, Brass LM, Mohsenin V: Obstructive sleep apnea as a risk factor for stroke and death. N Engl J Med 2005;353:2034-2041.

49 Peppard PE, Young T, Palta M, Skatrud J: Prospective study of the association between sleep-disordered breathing and hypertension. N Engl J Med 2000;342:1378-1384

50 Fletcher EC, Schaaf JW, Miller J, Fletcher JG: Long-term cardiopulmonary sequelae in patients with sleep apnea and chronic lung disease. Am Rev Respir Dis 1987;135:525533.

51 Sajkov D, Cowie RJ, Thornton AT, Espinoza HA, McEvoy RD: Pulmonary hypertension and hypoxemia in obstructive sleep apnea syndrome. Am J Respir Crit Care Med 1994; 149:416-422.

52 Sajkov D, Wang T, Saunders NA, Bune AJ, Neill AM, Douglas MR: Daytime pulmonary hemodynamics in patients with obstructive sleep apnea without lung disease. Am J Respir Crit Care Med 1999;159:1518-1526.

53 Galie N, Humbert M, Vachiery JL, Gibbs S, Lang I, et al: 2015 ESC/ERS Guidelines for the diagnosis and treatment of pulmonary hypertension: The Joint Task Force for the Diagnosis and Treatment of Pulmonary Hypertension of the European Society of Cardiology (ESC) and the European Respiratory Society (ERS): Endorsed by: Association for European Paediatric and Congenital Cardiology (AEPC), International Society for Heart and Lung Transplantation (ISHLT). Eur Heart J 2016;37:67-119.

-54 Schulz R, Baseler G, Ghofrani HA, Grimminger F, Olschewski $H$, Seeger W: Nocturnal periodic breathing in primary pulmonary hypertension. Eur Respir J 2002;19:658-663.

55 Minai OA, Pandya CM, Golish JA, Avecillas JF, McCarthy K, Marlow S, Arroliga AC: Predictors of nocturnal oxygen desaturation in pulmonary arterial hypertension. Chest 2007; 131:109-117.

56 Rafanan AL, Golish JA, Dinner DS, Hague LK, Arroliga AC: Nocturnal hypoxemia is common in primary pulmonary hypertension. Chest 2001;120:894-899.

57 Latshang TD, Furian M, Aeschbacher SS, Ulrich S, Osmonov B, Mirrakhimov EM, Isakova J, Aldashev AA, Sooronbev TM, Bloch KE: Association between sleep apnoea and pulmonary hypertension in Kyrgyz highlanders. Eur Respir J, in press.

58 Fletcher EC, Levin DC: Cardiopulmonary hemodynamics during sleep in subjects with chronic obstructive pulmonary disease. The effect of short- and long-term oxygen. Chest 1984;85:6-14.

59 Sajkov D, Wang T, Saunders NA, Bune AJ, McEvoy RD: Continuous positive airway pressure treatment improves pulmonary hemodynamics in patients with obstructive sleep apnea. Am J Respir Crit Care Med 2002; 165:152-158. 
60 Arias MA, Garcia-Rio F, Alonso-Fernandez A, Martinez I, Villamor J: Pulmonary hypertension in obstructive sleep apnoea: effects of continuous positive airway pressure: a randomized, controlled cross-over study. Eur Heart J 2006;27:1106-1113.

-61 Cranston JM, Crockett AJ, Moss JR, Alpers $\mathrm{JH}$ : Domiciliary oxygen for chronic obstructive pulmonary disease. Cochrane Database Syst Rev 2005;4:CD001744.

62 Ulrich S, Keusch S, Hildenbrand FF, Lo CC, Huber LC, Tanner FC, Speich R, Bloch KE: Effect of nocturnal oxygen and acetazolamide on exercise performance in patients with precapillary pulmonary hypertension and sleepdisturbed breathing: randomized, doubleblind, cross-over trial. Eur Heart J 2015;36: 615-623.
63 Sanner BM, Konermann M, Sturm A, Muller HJ, Zidek W: Right ventricular dysfunction in patients with obstructive sleep apnoea syndrome. Eur Respir J 1997;10:2079-2083.

64 Schulz R, Fegbeutel C, Olschewski H, Rose F, Schafers HJ, Seeger W: Reversal of nocturnal periodic breathing in primary pulmonary hypertension after lung transplantation. Chest 2004; 125:344-347.

65 Hildenbrand FF, Bloch KE, Speich R, Ulrich S: Daytime measurements underestimate nocturnal oxygen desaturations in pulmonary arterial and chronic thromboembolic pulmonary hypertension. Respiration 2012; 84:477-484.

66 Dumitrascu R, Tiede H, Eckermann J, Mayer K, Reichenberger F, Ghofrani HA, Seeger W, Heitmann J, Schulz R: Sleep apnea in precapillary pulmonary hypertension. Sleep Med 2013;14:247-251.
67 Colish J, Walker JR, Elmayergi N, Almutairi S, Alharbi F, Lytwyn M, Francis A, Bohonis S, Zeglinski M, Kirkpatrick ID, Sharma S, Jassal DS: Obstructive sleep apnea: effects of continuous positive airway pressure on cardiac remodeling as assessed by cardiac biomarkers, echocardiography, and cardiac MRI. Chest 2012;141:674-681.

68 Marvisi M, Vento MG, Balzarini L, Mancini C, Marvisi C: Continuous positive airways pressure and uvulopalatopharyngoplasty improves pulmonary hypertension in patients with obstructive sleep apnoea. Lung 2015;193: 269-274. 